\title{
The Role of Mediating the Publication on the Influence of Corporate Governance on Performance
}

\author{
Suwardi Bambang Hermanto \\ \{sbhermanto@stiesia.ac.id\} \\ Indonesia School of Economics (STIESIA) Surabaya, \\ Jl. Menur Pumpungan 30 Surabaya, Indonesia 60118
}

\begin{abstract}
The aim of the study was to analyze the mediating role of the financial report published on the effect of corporate governance on the performance of Indonesian public companies. The corporate governance proxy consists of ownership, independence of directors and commissioners, meetings of directors and audit committees, as well as the number of commissioners and audit committees. The research samples of 775 annual reports 2013-2014 were chosen proportionally strata, from nine industry groups. The results of multiple regression analysis found that directors and independent commissioners, as well as the frequency of audit committee meetings, had a significant effect on performance. Whereas ownership, meetings of directors and audit committees, and the number of commissioners and audit committees have a significant effect on publications. Publication of financial statements significantly as a mediation of the effect of corporate governance on performance.
\end{abstract}

Keywords: Publication, Corporate governance, Performance.

\section{Introduction}

The performance of public companies is a concern for investors and shareholders because of the separation between managers and company owners. Performance information can be obtained through publications by issuers. Issuers on the Indonesia Stock Exchange (BEI) have the obligation to submit annual financial reports to Bapepam and LK and be announced to the public. Publication of financial statements no later than the end of the third month after the date of the annual financial report [1].

The importance of the speed of publication of annual financial statements because it reduces information uncertainty for decision making in the capital market. Regulations in several countries make it a priority to speed up publication time [2]. The speed of publication as an important component is relevant for accounting regulators and capital market authorities throughout the world [3]. For example, regulators on the New York Stock Exchange (NYSE) and NASDAQ, since 2002 have established a time lag for publishing annual financial reports from 90 days to 60 days.

The speed at which stakeholders publish financial statements as information is still fresh for decision making. Publication of financial statements as one of the attributes of corporate governance effectiveness identified by the Organization for Economic Co-operation and Development (OECD) and the World Bank [4]. Therefore, corporate governance effectiveness can affect the speed at which financial statements are published. 
Corporate governance in Indonesia has five principles [5], namely: (1) transparency, (2) accountability, (3) responsibility, (4) independence and (5) fairness. These five principles can be guidelines in corporate governance mechanisms, and the corporate governance mechanism literature influences financial performance [6], [7], [8]. Therefore, there are three interrelated variables, namely: (1) publication of financial statements, (2) corporate governance, and (3) financial performance.

Publication of financial statements significantly influences the company's financial performance as measured by returns on equity [9]. In addition, corporate governance has an effect on financial reporting publications [10], [11]. So, corporate governance can directly affect the performance and publication of financial statements, while the publication of financial statements affects financial performance.

Therefore, this study will analyze the effect of corporate governance on the speed of publication and its effect on financial performance. With the aim of obtaining empirical findings that are useful for the functioning of capital market regulations in Indonesia. Then, the research question is: how is the mediating role of publication on the influence of corporate governance on the issuer's financial performance on the Indonesian Stock Exchange?.

\section{Materials and Methods}

\subsection{Theoretical framework}

The theoretical support of corporate governance practices and their effects on report publications and company performance, in the literature, is dominated by agency theory and stakeholder theory. The characteristics of corporate governance in various research are used by corporate governance mechanisms as a proxy for their measurement. Therefore, a theoretical review in this study describes agency theory, stakeholder theory, and corporate governance mechanisms.

\subsubsection{Agency theory}

Agency theory is a contractual relationship between the agent (management) and the principal (owner). In this theory, the principal gives orders to the agent to manage the company on behalf of the principal. Then, the principal delegates his authority to manage the company to the agent to make the best decision for the principal [12].

In the contractual implementation, agents who master company information can hide information from the owner, to be used to make decisions in maximizing its utilization. So, management does not always behave best for the benefit of the owner or can injure the contractual [13]. This condition causes agency conflict to cause agency costs. One of the costs is monitoring the behavior of agents in the form of financial statement audit fees that are a burden on the principal. In many cases, agency conflict occurs because of the lack of effective corporate governance mechanisms for efficient control [14].

The corporate governance mechanism is a procedure that can control the company, in order to provide added value to sustainable stakeholders. For companies in Indonesia, they must ensure that the principles of corporate governance are applied to every aspect of the business and in all levels of the company. The application is based on the principles of transparency, accountability, responsibility, independence, and fairness and equality, to achieve the sustainability of the company's business by paying attention to stakeholders or 
stakeholders [5]. Therefore, agency theory supports the implementation of corporate governance in Indonesia.

\subsubsection{Stakeholders theory}

Stakeholder theory is defined as a group or individual who can influence or be influenced by the achievement of organizational goals [13]. Stakeholders include shareholders, employees, customers, creditors, suppliers, and various interest groups and the government. In the view of stakeholder theory that shareholders are not the only stakeholders, and all stakeholders have the right to be given information about how the organization affects them (perhaps through pollution, community sponsorship, providing employment, safety initiatives, etc.). Even if they choose to do not use information or stakeholders cannot directly influence the survival of the organization [13]. Providing information will increase the transparency of company activities. Therefore, stakeholder theory can support companies to achieve one of the mechanisms of corporate governance on the principle of transparency.

Effective implementation of corporate governance, based on agency theory, is expected to reduce agency conflict. Its implementation is with the obligation to apply transparency, accountability, responsibility, independence, and fairness, by paying attention to stakeholders [5]. Therefore, the combination of agency theory and stakeholder theory is used as the theoretical basis, in this study.

\subsubsection{Corporate governance mechanism}

Corporate governance mechanisms at the company level include a general meeting of shareholders, a board of commissioners and directors as company organs. Company organs have an important role in implementing corporate governance effectively [5]. Therefore, the mechanism of corporate governance is used to measure the effectiveness of corporate governance. The corporate governance mechanism consists of ownership, independence and number of commissioners, independence and number of directors, and frequency of meetings and audit committees.

The share ownership share as the composition of the number of shares held by shareholders to be able to control the management of public companies. The share ownership is above $5 \%$ as institutional ownership. The large portion of ownership has controls that can put pressure on transparency in the publication of financial statements [15]. The composition of institutional ownership affects company value [7].

The Commissioner as a company organ has the duty and responsibility collectively to supervise and provide advice to the Board of Directors and ensure that the company implements corporate governance. The composition of commissioners must enable decision making effectively, precisely and quickly, and can act independently [5]. The attributes of the commissioner's independence and the number of commissioners' effectiveness affect the speed of financial report publishing [15]. Independent commissioners influence company value [7].

The Board of Directors as a corporate organ has a collegian duty and responsibility in managing the company. The composition of directors must enable decision making effectively, precisely and quickly, and can act independently. Directors must be professional and responsible for generating profitability and ensuring the sustainability of the company's business [5]. The independence of directors' attributes and the frequency of board meetings affect the publication of report speed [15], [16]. The size of directors influences company performance [17].

The audit committee is a supporter of the board of commissioners, whose duty is to ensure that financial statements are fairly presented in accordance with generally accepted 
accounting principles (KNKG, 2006). The frequency effectiveness of meetings and the number of audit committees influence the speed of financial report publication [18]; [19].

Therefore, effective corporate governance mechanisms can affect financial performance and can also affect the speed of financial report publishing.

\subsection{Development of hypotheses}

Hypothesis development consists of three relationship groups, namely: (1) corporate governance mechanism on performance and publication, (2) corporate governance on overall performance and publication, and (3) mediating role of publication on the effect of corporate governance on performance.

\subsubsection{Effect of the mechanism of corporate governance on performance and publication}

Corporate governance mechanisms are used to proxy ownership, directors, commissioners and audit committees, which affect performance and publication.

a. Ownership of performance and publications

Ownership is the number of shares held as the number of voting rights in the company. The amount of ownership can control the company according to its interests. Control in ownership can direct the management of the company to achieve performance as planned. Thus, institutional ownership has a positive effect on firm value [6], [7].

Corporate governance practices that can effectively control can guarantee the acquisition of information for minority ownership. So the large portion of ownership can encourage company management to accelerate publication. Therefore, the higher the portion of ownership will affect the short time for publication [10], [11], [15], the hypothesis is arranged: H1a: The portion of ownership (OWP) has a positive effect on performance (PER). $\mathrm{H} 2 \mathrm{a}$ : Ownership portion (OWP) has a negative effect on publication (PUB).

b. Directors on performance and publications

Directors are responsible for delivering company information to the commissioner. Each director and commissioner must report ownership to the company. The directors of BEI issuers are at least an independent director, and the independent composition will have a contribution to decision making. Therefore, the independence of directors will affect the achievement of company performance [8] and the high independence of directors will shorten the publication time [11], [15], the hypothesis is arranged:

H1b: The proportion of independent directors (DIP) has a positive effect on performance (PER).

H2b: The proportion of independent directors (DIP) has a negative effect on publications (PUB).

Directors' meetings must be conducted at least once a month, and the frequency and intensity of meetings will have an impact on the performance and completion of management reports. Therefore, the frequency of board meetings will affect performance achievement [8], as well as shorten the completion time of reports for publications [11], [20], [21], the hypothesis is arranged:

H1c: Director's meeting frequency (DIM) has a positive effect on performance (PER)

$\mathrm{H} 2 \mathrm{c}$ : Frequency of board meetings (DIM) has a negative effect on publications (PUB)

c. Commissioners on performance and publications 
The Commissioner is responsible for conducting general and special supervision and giving advice to the directors. The number of commissioners is at least two people, and one of them is independent, if there are more than two commissioners, then at least $30 \%$ of the total commissioners must be independent, so the emphasis is on independence and the amount. Independence as an important component of corporate governance, and the independence of commissioners influence the achievement of company performance [22], [8], and the higher the independence of commissioners will shorten the time for financial report publication [23], [3], [16]. Independence of commissioners controls the quality of financial statement information (transparency), and encourages the acceleration of audit financial reports, and [21], the hypothesis is arranged:

H1d: Independence of commissioners (COP) has a positive effect on performance (PER).

$\mathrm{H} 2 \mathrm{~d}$ : Independence of commissioners (COP) has a negative effect on publications (PUB).

The number of commissioners will influence the intensity of supervision that produces performance [6], [8], and more and more commissioners will have less time to immediately publish financial reports [3], [16], it is arranged in the hypothesis:

H1e: Number of commissioners (CON) has a positive effect on performance (PER).

$\mathrm{H} 2 \mathrm{e}$ : Number of commissioners (CON) has a negative effect on publications (PUB).

d. Audit Committee on performance and publication

The audit committee plays a role in management relations, internal auditors and external auditors over the three priority controls [24]: (1) effective supervision of financial management and reporting, (2) strengthening management communication with external auditors, (3) knowledge independence.

The number of audit committees will increase the value of the company [25], and the audit committee can oversee the financial accounting reporting process (Zhizhong et al., 2011). The number of audit committees that have accounting and financial expertise will be more effective in shortening the time for publication [2], [18], the hypothesis is arranged:

H1f: The number of audit committees (CAN) has a positive effect on performance (PER).

H2f: The number of audit committees (CAN) has a negative effect on publications (PUB).

Audit committee activities can be reflected by the frequency of audit committee meetings. Audit committee meetings can oversee the financial accounting process, because of their expertise and experience (Zhizhong et al., 2011), [2], [27]. The frequency of meetings can affect improving company performance with qualified auditors [28]. The existence, independence and expertise of the audit committee can produce meeting effectiveness that speeds up the publication of financial statements [10], [11], [20], [29], [18], the hypothesis is arranged:

H1g: Frequency of audit committee meetings (CAM) has a positive effect on performance (PER).

$\mathrm{H} 2 \mathrm{~g}$ : The frequency of audit committee meetings (CAM) has a negative effect on publications (PUB).

\subsubsection{Effect of corporate governance and publication on performance}

Corporate governance as a whole as the effectiveness of corporate governance mechanisms that affect performance and publication. Therefore, the sum of the values of the corporate governance mechanism variables that significantly influence performance and publication. The effectiveness of corporate governance has a positive effect on performance [25], [22], [25], [6], [7], [8], then hypothesis is arranged: .

$\mathrm{H} 1$ : Corporate governance (CGO) has a positive effect on performance (PER) 
The high measure of the effectiveness of the application of corporate governance will reduce the low time needed to immediately publish financial statements [10], [21], [11], [2], [18], [20], [29], (Zhizhong et al., 2011), [15], [3], then the hypothesis is arranged:

$\mathrm{H} 2$ : Corporate governance (CGO) has a negative effect on publications (PUB)

Publication of the issuer's financial statements on the IDX to the public, no later than the end of the third month after the date of the annual financial report [1]. The speed of publication will reflect effective corporate governance practices, which are influenced by the timing of audit completion [30]. Audit report lag is measured by the number of days from the end of the year to the date of the audit report (Abernathy et al., 2015). The low size of audit completion days will speed up publications that affect the high financial performance [9] because it provides certainty information in financial statement disclosures, the hypothesis is arranged:

H3: Publication (PUB) influences negatively on performance (PER)

\subsubsection{Role of publication as mediation effect of corporate governance on performance}

Publication of financial statements influences financial performance [9], while corporate governance also influences financial performance [25], [22], [25], [6], [7], [8], and corporate governance also influence publications [10], [21], [11], [2], [18], [20], [29], (Zhizhong et al., 2011), [15], [3]. So, publication variables can be the mediation of the effect of corporate governance on performance. Therefore, hypotheses are arranged:

H4: Publication (PUB) as a mediation of the effect of corporate governance (CGO) on performance (PER)

\subsection{Research model}

The research model and hypothesis compiled in Figure 1, of corporate governance variables as independent variables and performance as the dependent variable with a positive direction. While publication as a mediating variable with a negative direction. Corporate governance in its mechanism consists of: (a) Ownership, (b) Independent directors, (c Board of directors meetings, (d) Independent commissioners, (e) Number of commissioners, (f) Number of audit committees, and (g) Audit committee meetings.

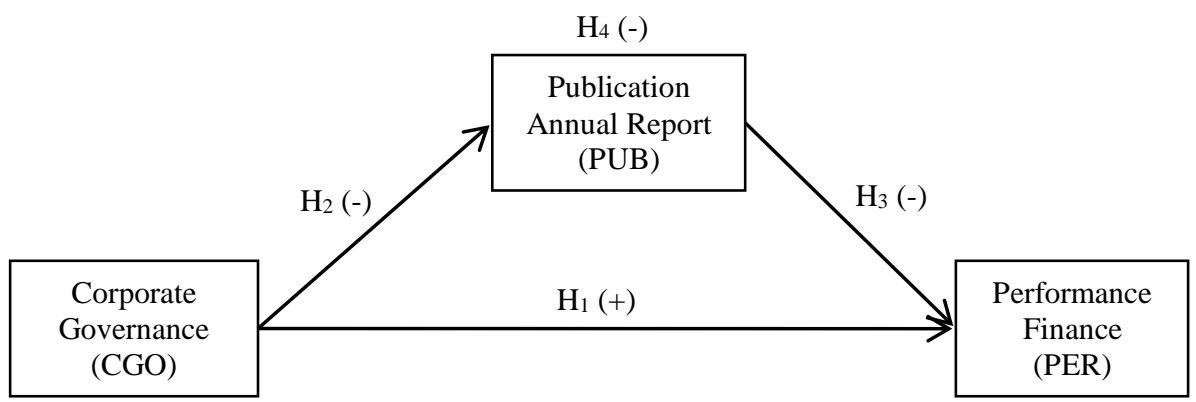

Figure 1. Research Model

\subsection{Methodology}

\subsubsection{Population and samples}

The research population is public companies on the IDX in 2013-2014 which publish annual reports from nine industry classifications: (1) agriculture, (2) mining, (3) basic industry 
and chemicals, (4) miscellaneous industry, (5) consumer goods industry , (6) property, real estate and building constructions, (7) infrastructures, utilities and transportation, (8) finance, and (9) trade, services and investment.

Stratified random samples according to industry classifications for good generalization are set at $90 \%$ proportional, with secondary data downloaded on the IDX official website at www.idx.co.id.

\subsubsection{Operational definition of variables}

The operational definition of variables from the dependence, independent and control variables is presented in Table 1.

Table 1. Operational Definition of Variables

\begin{tabular}{|c|c|c|c|c|}
\hline Code & Variables & Definition of measurement & Scale & Ref. Authors \\
\hline PER & $\begin{array}{l}\text { Company } \\
\text { performance }\end{array}$ & $\begin{array}{l}\text { The company's success is calculated from } \\
\text { Return on Assets }\end{array}$ & $\begin{array}{c}\text { Ratio } \\
\text { (percent) }\end{array}$ & {$[15]$} \\
\hline OWP & $\begin{array}{l}\text { Portion to } \\
\text { Ownership }\end{array}$ & $\begin{array}{l}\text { The composition of the number of shares } \\
\text { ownership }>5 \% \text { of the total outstanding } \\
\text { shares }\end{array}$ & $\begin{array}{l}\text { Ratio } \\
\text { (percent) }\end{array}$ & [15] \\
\hline DIP & $\begin{array}{l}\text { Portion of } \\
\text { independent } \\
\text { directors }\end{array}$ & $\begin{array}{l}\text { The composition of independent directors } \\
\text { towards total directors }\end{array}$ & $\begin{array}{c}\text { Ratio } \\
\text { (percent) }\end{array}$ & [15] \\
\hline DIM & $\begin{array}{l}\text { Board of } \\
\text { directors } \\
\text { meeting }\end{array}$ & $\begin{array}{l}\text { The activities of directors are calculated by } \\
\text { the number of frequency of meetings of } \\
\text { directors a year }\end{array}$ & $\begin{array}{l}\text { Ratio } \\
\text { (event) }\end{array}$ & [20] \\
\hline $\mathrm{COP}$ & $\begin{array}{l}\text { Portion of } \\
\text { independent } \\
\text { commissioners }\end{array}$ & $\begin{array}{l}\text { The composition of independent } \\
\text { commissioners to the total commissioner's }\end{array}$ & $\begin{array}{c}\text { Ratio } \\
\text { (percent) }\end{array}$ & [15] \\
\hline $\mathrm{CON}$ & $\begin{array}{l}\text { Number of } \\
\text { commissioners }\end{array}$ & Number of commissioner personnel & $\begin{array}{l}\text { Ratio } \\
\text { (person) }\end{array}$ & [18] \\
\hline CAN & $\begin{array}{l}\text { Number of audit } \\
\text { committees }\end{array}$ & Number of audit committee personnel & $\begin{array}{l}\text { Ratio } \\
\text { (person) }\end{array}$ & {$[18]$} \\
\hline CAM & $\begin{array}{l}\text { Audit committee } \\
\text { meetings }\end{array}$ & $\begin{array}{l}\text { The number of years of audit committee } \\
\text { meetings }\end{array}$ & $\begin{array}{l}\text { Ratio } \\
\text { (event) }\end{array}$ & [18] \\
\hline PUB & $\begin{array}{l}\text { Publication } \\
\text { annual report }\end{array}$ & $\begin{array}{l}\text { Timeliness, from the date of the audit date } \\
\text { to the end of the audit report date. }\end{array}$ & $\begin{array}{l}\text { Ratio } \\
\text { (days) }\end{array}$ & $\begin{array}{l}\text { (Abernathy et } \\
\text { al., 2015) }\end{array}$ \\
\hline
\end{tabular}

Source: (Abernathy et al., 2015); [15]; [20]; [18].

\subsubsection{Analysis techniques}

The analysis technique uses SPSS software (Statistical Package for Social Science ver. 20), presents: (1) descriptive statistics for statistically minimum, maximum, mean and standard deviation characteristics, and (2) inferential statistics to test classical assumptions, goodness -fit model and simultaneous influence, as well as hypothesis testing.

The research model specifications, grouped into two hypothesis testing models, the first hypothesis testing model of corporate governance mechanisms, and the two publication mediation testing models.

The first model with multiple regression equations, as follows:

$\mathrm{PER}=\alpha 1+\beta 1 \mathrm{aOWP}+\beta 1 \mathrm{bDIP}+\beta 1 \mathrm{cDIM}+\beta 1 \mathrm{dCOP}+\beta 1 \mathrm{eCON}+\beta 1 \mathrm{fCAN}+\beta 1 \mathrm{gCAM}+\varepsilon 1$ $\mathrm{PUB}=\alpha 2+\beta 2 \mathrm{aOWP}+\beta 2 \mathrm{bDIP}+\beta 2 \mathrm{cDIM}+\beta 2 \mathrm{dCOP}+\beta 2 \mathrm{eCON}+\beta 2 \mathrm{fCAN}+\beta 2 \mathrm{gCAM}+\varepsilon 2 \ldots$ (2) Where: 


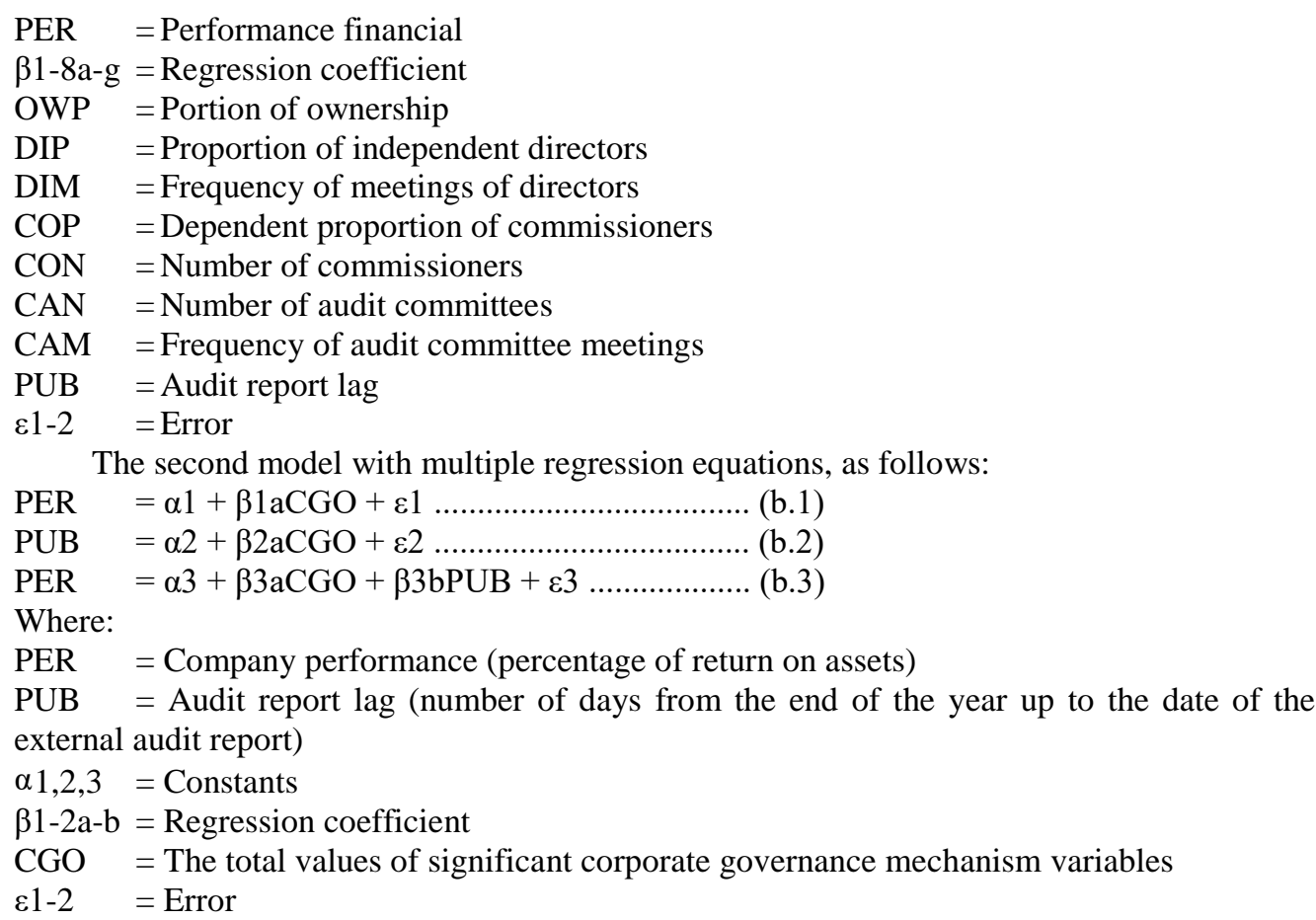

\section{Results}

\subsection{Overview of research objects}

The object of research by public companies on the IDX in 2013-2014 which published an annual report of 1,010 as a population, with long experience of listing and size of the company, in implementing corporate governance is very diverse.

The stratified random sample method of $90 \%$ of the population obtained 909 annual reports, minus 134 whose data is incomplete, so that can be used as a sample of 775 observations from nine industry classifications or $77 \%$ of the population.

Table 2. Research Samples

\begin{tabular}{clrrrc}
\hline Code & \multicolumn{1}{c}{ Industrial Classification } & Annual & Remove & Sample & Proportion \\
\hline 1 & Agriculture & 37 & 1 & 36 & 0.88 \\
2 & Mining & 72 & 15 & 57 & 0.71 \\
3 & Basic Industry \& Chemical & 115 & 8 & 107 & 0.84 \\
4 & Miscellaneous Industry & 73 & 13 & 60 & 0.74 \\
5 & Consumer Good Industry & 68 & 12 & 56 & 0.74 \\
6 & Property, Real Estate \& Building Constructions & 98 & 7 & 91 & 0.84 \\
7 & Infrastructure,Utilities \& Transportation & 92 & 23 & 69 & 0.68 \\
8 & Finance & 151 & 13 & 138 & 0.82 \\
9 & Trade, Service \& Investment & 203 & 42 & 161 & 0.71 \\
\hline & Total & 1,010 & 134 & 775 & 0.77 \\
\hline
\end{tabular}

Source: Researcher (2018). The results of the research data process. 


\subsection{Descriptive statistics}

Financial performance (PER) has an average ROA of $4.21 \%$ per company and $16.6 \%$ of the samples have negative ROA or loss, with a minimum of $-37.83 \%$ and a maximum of $42.99 \%$ and a standard deviation of $8.24 \%$ indicating the variety of sample data.

Ownership $>5 \%$ (OWP) is the portion of voice owners to be able to make important decisions at the GMS, of the total sample there are 69 companies or $11.2 \%$ total ownership shares $<50 \%$, which means that the majority shareholders are shareholders $<5 \%$. On average $70.77 \%$ of the ownership of each company, so the portion of the ownership has a control role in the company.

Independent directors (DIP) have an average proportion of $18.9 \%$ per company and $51 \%$ of the total sample has a proportion of $0-18.9 \%$ independent, and the frequency of board of directors meetings (DIM) averages 14 times a year for each company and as many as $76 \%$ of the sample meets $2-14$ times a year.

The independent commissioner (COP) has an average proportion of $42 \%$ per company, and there are $3.4 \%$ of the samples with the proportion of independent $<30 \%$. The average number of commissioners (CON) is 4 personnel per company, and in total $63 \%$ of the samples have $2-4$ commissioners.

The audit committee (CAN) averages three personnel per company, and $90 \%$ of the samples have an audit committee of 2-3 people. The frequency of meetings (CAM) averages six meetings a year for each company, and 76\% of the samples meet 1-6 times a year.

Publication (PUB) is an audit report lag which shows the number of days in the completion of 2013-2014 public company audit which is the fastest 30 days and no later than 127 days and an average of 75 days from the end of the year, and $95.9 \%$ of the samples are not late or completed in within 90 days, and 32 companies are late.

Table 3. Descriptive Statistics

\begin{tabular}{lrrrrr}
\hline Code-Variables & $\mathrm{N}$ & Minimum & Maximum & Mean & Std.Dev. \\
\hline PER -Performance financial & 775 & -37.83 & 42.99 & 4.21 & 8.24 \\
OWP -Ownership & 775 & 5.97 & 98.96 & 70.77 & 17.97 \\
DIP -Proportion of independent directors & 775 & .00 & 75.00 & 18.09 & 16.48 \\
DIM -Meeting of directors & 775 & 2.00 & 82.00 & 13.88 & 12.34 \\
COP -Proportion of independent commissioners & 775 & 16.67 & 80.00 & 42.11 & 11.58 \\
CON -Number of commissioners & 775 & 2.00 & 12.00 & 4.15 & 1.73 \\
CAN -Number of audit committees & 775 & 2.00 & 7.00 & 3.11 & .54 \\
CAM -Audit committee meeting & 775 & 0.00 & 59.00 & 6.36 & 5.91 \\
PUB -Publication & 775 & 30.00 & 127.00 & 74.69 & 15.55 \\
Valid N (listwise) & 775 & & & & \\
\hline Soure: Resear
\end{tabular}

Source: Researcher (2018), Output of SPSS process.

\subsection{Inferential statistics}

Multiple regression analysis is used in research, by presenting the classic assumption test, and the goodness of fit model, and hypothesis testing. 
3.3.1 Classical Assumption Test and Goodness of Fit Model

Normality test using One-Sample Kolmogorov-Smirnov, Test that the data, is not normal, then the semi-log regression model is used with the transformation of natural logarithms (Ln) dependent variable and fixed independent variables, and test results in Table 4.

Table 4. One-Sample Kolmogorov-Smirnov Test

\begin{tabular}{llr}
\hline & & Unstandardized Residual \\
\hline $\mathrm{N}$ & & 775 \\
Normal Parameters & Mean & .000 \\
& Std.Deviation & .729 \\
& Absolute & .018 \\
Most Extreme Differences & Positive & .018 \\
& Negative & -.014 \\
Kolmogorov-Smirnov & & 1.488 \\
Asymp. Sig.(2-tailed) & & .097 \\
\hline a'Test distribution is Normal. & \\
bCalculated from data. & \\
Source: Researcher (2018), Output of the SPSS process.
\end{tabular}

Multicollinearity test between independent variables tolerance value does not exist $<0.10$ and there is no VIF value $>10$ (Table 5), as well as the correlation matrix between independent variables there is no value $>0.90$ (Table 6 ), then it is concluded that multicollinearity does not occur.

Tabel 5. Coefficients ${ }^{\mathrm{a}}$

\begin{tabular}{|c|c|c|c|c|c|c|c|}
\hline \multirow{2}{*}{ Model } & \multicolumn{2}{|c|}{$\begin{array}{c}\text { Unstandardized } \\
\text { Coefficients } \\
\end{array}$} & \multirow{2}{*}{ Beta } & \multirow{2}{*}{$\mathrm{T}$} & \multirow{2}{*}{ Sig } & \multicolumn{2}{|c|}{$\begin{array}{c}\text { Collinearity } \\
\text { Statistics } \\
\end{array}$} \\
\hline & B & $\begin{array}{c}\text { Std. } \\
\text { Error }\end{array}$ & & & & $\begin{array}{l}\text { Tole } \\
\text { Rance }\end{array}$ & VIF \\
\hline (Constant) & 15.19 & 3.21 & & 4.73 & .00 & & \\
\hline OWP-Ownership & -.29 & .02 & -.05 & -2.27 & .03 & .98 & 1.02 \\
\hline DIP -Proportion of independent directors & .00 & .03 & .00 & .03 & .97 & .84 & 1.19 \\
\hline DIM -Meeting of directors & -.20 & .02 & -.00 & -2.04 & .02 & .96 & 1.04 \\
\hline COP -Proportion of independent commiss. & .26 & 18 & .05 & 1.40 & .16 & .84 & 1.19 \\
\hline CON -Number of commissioners & -.30 & .03 & -.05 & -2.35 & .02 & .98 & 1.01 \\
\hline CAN -Number of audit committees & -.90 & .59 & -.06 & -2.53 & .01 & .82 & 1.22 \\
\hline CAM -Audit committee meeting & -.10 & .06 & -.00 & -3.02 & .01 & .82 & 1.23 \\
\hline PUB -Publication & -.28 & .02 & -.16 & -4.16 & .00 & .86 & 1.17 \\
\hline
\end{tabular}

${ }^{\mathrm{a}}$ Dependent Variable: PER

$* *=$ Significant $0.01 . ;=$ Significant 0.05 .

Source: Researcher (2018), Output of the SPSS process

Correlation matrix between independent variables Table 6 , shows no correlation $>0.90$, which means there is no Multicollinearity between independent variables. 
Table 8. Anova a

\begin{tabular}{llrrrrr}
\hline & Model & Sum of Squares & Df & Mean Square & F & \multicolumn{1}{c}{ Sig. } \\
\hline 1 & Regression & $1,839.378$ & 8 & 229.922 & 3.477 &, $001^{\text {b }}$ \\
Residual & $50,657.113$ & 766 & 66.132 & & \\
\cline { 3 - 4 } & $52,496.490$ & 774 & & & \\
\hline
\end{tabular}

${ }^{\text {a }}$ Dependent Variable: PER

b Predictors: (Constant), The proportion of ownership (OWP), the proportion of independent directors (DIP), board of directors (DIM), proportion of independent commissioners (COP), number of commissioners (CON), number of audit committees (CAN), audit committee meetings (CAM), publication (PUB).

Source: Researcher (2018), Output of the SPSS process.

\subsubsection{Hypothesis testing}

Hypothesis testing consists of two testing groups. The first is the influence of corporate governance mechanisms and the two mediating roles of publication on the effect of corporate governance on financial performance.

Table 9. Coefficients Regression Test of Corporate Governance Mechanism

\begin{tabular}{|c|c|c|c|c|c|c|}
\hline \multirow[b]{2}{*}{ Corporate governance mechanism variables } & \multicolumn{3}{|c|}{ Model a.1 } & \multicolumn{3}{|c|}{ Model a.2 } \\
\hline & $\begin{array}{c}\text { Unstandard } \\
\text { Coeff. } \beta\end{array}$ & t-value & $\begin{array}{l}\text { Test } \\
\text { result }\end{array}$ & $\begin{array}{c}\text { Unstandard } \\
\text { Coeff. } \beta\end{array}$ & t-value & $\begin{array}{l}\text { Test } \\
\text { result }\end{array}$ \\
\hline (Constant) & 6.41 & 2.62 & & 103.96 & 24.16 & \\
\hline OWP_Ownership & .31 & 2.84 & Sign & -.68 & -2.86 & Sign \\
\hline DIP -Proportion of independent directors & .01 & .46 & No & -.03 & -.91 & No \\
\hline DIM -Meeting of directors & .40 & 2.09 & Sign & -.43 & -2.89 & Sign \\
\hline COP -Proportion of independent commiss. & .44 & 1.40 & No & -.06 & -1.36 & No \\
\hline $\mathrm{CON}$-Number of commissioners & .23 & 2.13 & Sign & -.59 & -6.55 & Sign \\
\hline CAN -Number of audit committees & .71 & 2.18 & Sign & -.69 & -2.27 & Sign \\
\hline \multirow[t]{3}{*}{ CAM -Audit committee meeting } & .33 & 2.55 & Sign & -.37 & -3.79 & Sign \\
\hline & \multicolumn{3}{|c|}{0.272} & \multicolumn{3}{|c|}{0.425} \\
\hline & \multicolumn{3}{|c|}{ Performance (PER) } & \multicolumn{3}{|c|}{ Publication (PUB) } \\
\hline
\end{tabular}
Source: Researcher (2018), Output of SPSS process.

Based on Table 9, of the seven corporate governance mechanism variables, there are five variables that have a significant effect on performance variables and publication variables. For testing the role of publication mediation, the five significant variables are summed up as a proxy for corporate governance variables.

Table 10. Regression Analysis Mediation Variable Test

\begin{tabular}{|c|c|c|c|}
\hline & Model b.1 & Model b.2 & Model b.3 \\
\hline Dependend variable & PER & PUB & PER \\
\hline Intercept & 4.26 & 90.38 & 12.28 \\
\hline t-statistics & 3.31 & 38.38 & 5.68 \\
\hline COG (corporate governance) unstandardized coeff. $\beta$ & .06 & -.56 & -.02 \\
\hline$t$-statistics & **) 1.97 & $* * *)-6.84$ & $*)-1.13$ \\
\hline PUB (publication) unstandardized coefficients $\beta$ & & & -.51 \\
\hline t-statistics & & & $* * *) 4.58$ \\
\hline R Square & .18 & .47 & .62 \\
\hline Adjusted R Square & .11 & .39 & .52 \\
\hline
\end{tabular}


Based on Table 10 that model b. 1 that corporate governance has a significant effect on performance and the model b. 2 corporate governance has a significant effect on publication. In the b3 model testing together shows that corporate governance has no effect on performance. While the influence of publications is getting stronger against performance, as indicated by the rise in $\mathrm{R}^{2}$, from 0.47 to 0.62 . Therefore, the publication's role mediates the effect of corporate governance on performance. Then, the results of hypothesis testing are as follows:

$\mathrm{H} 1$ : Corporate governance has a positive effect on performance not accepted.

$\mathrm{H} 2$ : Corporate governance has a negative effect on accepted publications.

H3: Publications have a negative effect on acceptable performance.

H4: Publication mediating the effect of corporate governance on performance is accepted.

\section{Discussion}

Discussion of the results of this study is grouped into three discussions based on hypothesis testing. First, the influence of corporate governance mechanisms on performance and publication on each variable partially. Second, the influence of corporate governance and publication on overall performance, and third, the role of publication variables as a mediation of the effect of corporate governance on performance.

\subsection{Effects of corporate governance on performance}

H1a: The portion of ownership (OWP) has a positive effect on performance (PER). In Table 9, it shows the t-count value of 2.84 or> 1.965 which means that it is significant at 0.05 , then it cannot accept $\mathrm{H} 0$ or H1a accepted. The results of the study support research [6], [7] which states that corporate governance effectiveness has a positive effect on financial performance.

H2a: Ownership portion (OWP) has a negative effect on publication (PUB). In Table 9, it shows the t-count value of -2.86 or $>1,965$ which means that it is significant at 0.05 , then it cannot accept $\mathrm{H} 0$ or $\mathrm{H} 2 \mathrm{a}$ received. The results of the study support the study [10], [11] which states that the spread and concentration of share ownership has a negative effect on publications.

H1b: The proportion of independent directors (DIP) has a positive effect on performance (PER). In Table 9, it shows that the t-count value is 0.46 or $<1.965$ is not significant at 0.05 , then it cannot reject $\mathrm{H} 0$ or $\mathrm{H} 1 \mathrm{~b}$ rejected. The results of the study support the study [32] that independent directors do not contribute to company performance, but these results are contrary to research [8].

$\mathrm{H} 2 \mathrm{~b}$ : The proportion of independent directors (DIP) has a negative effect on publications (PUB). In Table 9, it shows that the t-count value is 0.46 or $<1.965$ is not significant at 0.05 , it cannot reject $\mathrm{H} 0$ or $\mathrm{H} 2 \mathrm{~b}$ is rejected. The results of the study support research (K.A.A. Daoud et al., 2014) and [29] that independent directors have no effect on ARL, but this result is contrary to research [15]. This finding can be explained that the role of independent directors in Indonesia is still low, such as 257 companies or one-third of the sample do not have independent directors. Therefore, the independent role of directors to improve performance and accelerate publication is still low.

H1c: The frequency of board meetings (DIM) has a positive effect on performance (PER). In Table 9, shows the value of $t$-count 2.09 or $>1.965$ which means that it is significant 
at 0.05 , then it cannot accept $\mathrm{HO}$ or H1c accepted. The results of the study support [8], the number of board meetings has a positive effect on financial performance.

H2c: Frequency of board meetings (DIM) has a negative effect on publications (PUB). In Table 9, the t-count value is -2.89 or $>1,965$ which means that it is significant at 0.05 , then it cannot accept $\mathrm{H} 0$ or H2c received. The results of the study support [21], [11], and [16] that the number of board meetings have a negative effect on publications.

H1d: The proportion of independent commissioners (COP) has a positive effect on performance (PER). In Table 9, it shows the value of t-count 1.40 or $<1.965$ which means it is not significant at 0.05 , then it cannot reject $\mathrm{H} 0$ or $\mathrm{H} 1 \mathrm{~d}$ rejected. The results of the study support [26] who did not find the effect of commissioner independence on performance, but did not support the study [22], [8]. This finding can be explained that independence is less of a role than commissioner expertise such as findings [27] as important characteristics of the commissioner.

H2d: The proportion of independent commissioners (COP) has a negative effect on publications (PUB). In Table 9, shows the value of the t-count value of -1.36 or $<1.965$ which means it is not significant at 0.05 , then it cannot reject $\mathrm{H} 0$ or $\mathrm{H} 2 \mathrm{~d}$ is rejected. The results of the study support [23] and [29] that independent commissioners have almost no effect on publications, but are contrary to research [21] and [15]. This finding can be explained that the role of independent commissioners in Indonesia is not optimal, also 26 companies have independent commissioners $<30 \%$, and commissioner expertise is not a research variable.

H1e: Number of commissioners $(\mathrm{CON})$ has a positive effect on performance (PER). In Table 9 , shows the value of t-count 2.13 or $>1.965$ which means that it is significant at 0.05 , then it cannot accept $\mathrm{HO}$ or H1e accepted. The results of the study support [6], [8] that the number of commissioners has a positive effect on financial performance.

H2e: Number of commissioners $(\mathrm{CON})$ has a negative effect on publications (PUB). In Table 9 , it shows the t-count value of -6.55 or $>1.965$ which means it is significant at 0.05 , then it cannot accept $\mathrm{H} 0$ or $\mathrm{H} 2 \mathrm{e}$ received. The results of the study support [3], [16] that the number of commissioners has a negative effect on publications.

H1f: The number of audit committees (CAN) has a positive effect on performance (PER). In Table 9, it shows the t-count value of 2.18 or> 1.965 which means that it is significant at 0.05 , then it cannot accept $\mathrm{H} 0$ or H1f received. The results of the study support [25] that the number of audit committees has a positive effect on publications.

H2f: The number of audit committees (CAN) has a negative effect on publications (PUB). In Table 9, it shows the t-count value of -2.27 or $>1,965$ which means significant at 0.05 , then it cannot receive $\mathrm{H} 0$ or $\mathrm{H} 2 \mathrm{f}$ received. The results of the study support [10], and [18] that the number of audit committees negatively affects publications.

H1g: Frequency of audit committee meetings (CAM) has a positive effect on performance (PER). In Table 9 , it shows the value of $\mathrm{t}$-count 2.55 or $>1.965$ which means that it is significant at 0.05 , then it cannot accept $\mathrm{H} 0$ or $\mathrm{H} 1 \mathrm{~g}$ accepted. The results of the study support [11], [18], [20], and [29] that the effectiveness of audit committees have a positive effect on financial performance.

$\mathrm{H} 2 \mathrm{~g}$ : The frequency of audit committee meetings (CAM) has a negative effect on publications (PUB). In Table 9, it shows the t-count value of -3.79 or $>1,965$ which means that it is significant at 0.05 , then it cannot accept $\mathrm{HO}$ or $\mathrm{H} 1 \mathrm{~g}$ accepted. The results of the study support [11], [18], [20], and [29] that the effectiveness of audit committees negatively affects publications. 


\subsection{Effects of corporate governance and publication on performance}

The effectiveness of corporate governance is partially measured by corporate governance mechanism variables. Whereas overall corporate governance testing is used the total value of the mechanism variable that significantly affects performance. The test results as presented in Table 10

H1: Corporate governance (CGO) has a positive effect on performance (PER). In Table 10 model b.3, shows the $t$-count value of -1.13 or $<1.965$ which means it is not significant, then it cannot reject $\mathrm{H} 0$ which means $\mathrm{H} 1$ is rejected. These results support the results of the study that the effect of corporate governance is not directly on financial performance, but contrary to the results of research [25], [22], [28], [6], [7], [8].

$\mathrm{H} 2$ : Corporate governance (CGO) has a negative effect on publications (PUB). In Table 10 , model b.2 shows the value of t-count of -6.84 or $>1,965$ which means that it is significant at 0.05 , then it not accepted $\mathrm{H} 0$ which means $\mathrm{H} 2$ is accepted. These results support the results of the study [10], [21], [11], [2], [18], [20], [29], (Zhizhong et al., 2011), [15], [3] that the high intensity of the application of corporate governance will affect the low time for reporting publication financial.

H3: Publication (PUB) has a negative effect on performance (PER). In Table 10 model b. 3, shows the t-count value of -4.58 or $>1,965$ which means that it is significant at 0.05 , then it not accepted $\mathrm{H} 0$ which means $\mathrm{H} 3$ is accepted. These results support the results of the study (Ojeka, 2018), that the publication of financial statements has a negative effect on financial performance.

\subsection{Role of publication as mediation effect of corporate governance on performance.}

H4: Publication (PUB) as a mediation of the effect of corporate governance on performance (PER). In Table 10 model b.1 that the direct effect of corporate governance (CGO) on performance without including publication variables (PUB) as mediation shows the t-count value of 1.97 or $>1.965$ which means significant at 0.05 . While in Table 10 model b.3 that the effect of corporate governance (CGO) on performance (PER by including the publication variable (PUB) shows the value of t-count 1.13 or $<1.965$ which means not significant. From the testing model b.1 and b. 3 after entering the publication variable (PUB) there is a decrease in influence (CGO) and not significant, which means that $\mathrm{H} 4$ is accepted. That publication variable as mediating the effect of corporate governance on performance.

\section{Conclusions}

Based on the results of hypothesis testing and discussion, the conclusions of this study are:

First, the corporate governance mechanism partially includes ownership variables, a frequency of board meetings, number of commissioners, number and frequency of audit committee meetings that have a positive effect on performance. Whereas the independence of directors and commissioners has no effect on performance and publications.

Second, the corporate governance mechanism partially includes ownership variables, a frequency of board meetings, number of commissioners, number and frequency of audit committee meetings that negatively affect publications.

Third, overall corporate governance has a negative effect on publications, and the publication of financial statements has a negative effect on performance. 
Fourth, the publication of financial statements as a mediation of the effect of corporate governance on performance, corporate governance does not directly affect performance.

Fifth, overall the model test results have R2 adjusted 0.52 or $52 \%$ variation in financial performance can be explained by variations in corporate governance and publication variables, while others are explained by variables outside the model.

Implications for future research can use corporate governance variables, corporate governance scoring indexes to provide results that reflect their application.

\section{References}

[1] Bapepam and LK, Keputusan Ketua Badan Pengawas Pasar Modal dan Lembaga Keuangan. 2011.

[2] J. Schmidt and M. S. Wilkins, "Bringing darkness to light: The influence of auditor quality and audit committee expertise on the timeliness of financial statement restatement disclosures," Audit. A J. Pract. Theory, vol. 32, no. 1, pp. 221-244, 2013.

[3] O. Abdelsalam and A. El-Masry, "The impact of board independence and ownership structure on the timeliness of corporate internet reporting of Irish-listed companies," Manag. Financ., vol. 34, no. 12 , pp. $907-918,2008$.

[4] R. W. McGee and X. Yuan, "Corporate governance and the timeliness of financial reporting: an empirical study of the people's republic of China," 2008.

[5] KNKG, "Pedoman Umum Good Corporate Governance Indonesia," Jakarta, 2006.

[6] L. Shao, "Dynamic study of corporate governance structure and fi $\mathrm{rm}$ performance in China Evidence from 2001-2015," Chinese Manag. Stud., vol. 9, no. 2, pp. 1-20, 2018.

[7] B. D. Handayani, "Mekanisme Corporate Governance, Enterprise Risk Management, dan Nilai Perusahaan Perbankan," J. Keuang. dan Perbank., vol. 21, no. 1, pp. 70-81, 2017.

[8] G. Palaniappan, "Determinants of corporate financial performance relating to board characteristics of corporate governance in Indian manufacturing industry An empirical study," Eur. J. Manag. Bus. Econ., vol. 26, no. 1, pp. 67-85, 2017.

[9] S. A. Ojeka, D. O. Mukoro, and C. Kanu, "Does Financial Reporting Disclosures Enhance Firm Financial Performance in the Nigerian Manufacturing Companies ?," Mediterr. J. Soc. Sci., vol. 6, no. 6, pp. 332-338, 2015.

[10] Y. M. Hassan, "Determinants of audit report lag: Evidence from Palestine," J. Account. Emerg. Econ., vol. 6, no. 1, pp. 13-32, 2016.

[11] K. Apadore and M. M. Noor, "Determinants of Audit Report Lag and Corporate Governance in Malaysia," Int. J. Bus. Manag., vol. 8, no. 15, pp. 151-163, 2013.

[12] M. C. Jensen and W. H. Meckling, "Theory of the Firm: Agency Costs and Ownership Structure," J. financ. econ., vol. 3, pp. 305-360, 1976.

[13] A. Al Mamun, Q. R. Yasser, and M. A. Rahman, "A Discussion of the Suitability of Only One vs More than One Theory for Depicting Corporate Governance," Mod. Econ., vol. 4, no. January, pp. 37-48, 2013.

[14] V. Ongore and P. K'Obonyo, "Effects of Selected Corporate Governance Characteristics on Firm Performance: Empirical Evidence from Kenya," Int. J. Econ. ..., vol. 1, no. 3, pp. 99-122, 2011.

[15] H. A. E. Afify, "Determinants of audit report lag: Does implementing corporate governance have any impact? Empirical evidence from Egypt," J. Appl. Account. Res., vol. 10, no. 1, pp. 56-86, 2009.

[16] U. J. B. Hashim and R. B. A. Rahman, "Board independence, board diligence, board expertise and impact on audit report lag in Malaysian market," Electron. copy, 2011.

[17] R. K. Mishra and S. Kapil, "Board characteristics and firm value for Indian companies," J. Indian Bus. Res., vol. 10, no. 1, pp. 2-32, 2018.

[18] S. R. Ika and N. A. M. Ghazali, "Audit committee effectiveness and timeliness of reporting: 
Indonesian evidence," Manag. Audit. J., vol. 27, no. 4, pp. 403-424, 2012.

[19] B. S. Bemby, Abukosim, Mukhtaruddin, and I. Mursidi, "Good Corporate Governance (GCG) Mechanism and Audit Delay: An Empirical Study on Companies Listed on the Indonesia Stock Exchange (IDX) in the Period of 2009-2011," J. Mod. Account. Audit., vol. 9, no. 11, pp. 1454-1468, 2013.

[20] U. J. B. Hashim and R. B. A. Rahman, "Audit report lag and the effectiveness of audit committee among Malaysian listed companies," Int. Bull. Bus. Adm., vol. 10, no. 1, pp. 50-56, 2011. [21] K. A. A. Daoud, K. N. I. K. Ismail, and N. A. Lode, "The impact of internal corporate governance on the timeliness of financial reports of Jordanian firms: Evidence using audit and management report lags," Mediterr. J. Soc. Sci., vol. 6, no. 1, pp. 430-442, 2015.

[22] W. Li, "Corporate governance evaluation of Chinese listed companies," Nankai Bus. Rev. Int., vol. 9, no. 4, pp. 437-456, 2018.

[23] Y. Li, D. Zhang, and X. Wang, "The Influence of Corporation Governance Structure on Internal Control Audit Report Lag: Evidence from China," Account. Tax., vol. 6, no. 2, pp. 101-115, 2014.

[24] A. Lambe, "Audit Committees step into the limelight," Account. Ireland, Feb, vol. 37, no. 1, pp. 48-51, 2005.

[25] P. Agyemang-Mintah and H. Schadewitz, "Audit committee adoption and firm value: evidence from UK financial institutions," Int. J. Account. Inf. Manag., vol. 26, no. 1, pp. 205-226, 2018.

[26] H. Zhizhong, Z. Juan, S. Yanzhi, and X. Wenli, "Does corporate governance affect restatement of financial reporting? Evidence from China," Nankai Bus. Rev. Int., vol. 2, no. 3, pp. 289-302, 2011.

[27] J. L. Abernathy, B. Beyer, A. Masli, and C. Stefaniak, "The association between characteristics of audit committee accounting experts, audit committee chairs, and financial reporting timeliness," Adv. Account., vol. 30, no. 2, pp. 283-297, 2014.

[28] M. Mahrani and N. Soewarno, "The effect of good corporate governance mechanism and corporate social responsibility on financial performance with earnings management as mediating variable," Asian J. Account. Res., vol. 3, no. 1, pp. 41-60, 2018.

[29] S. P. Nelson and S. N. . Shukeri, "Corporate governance and audit report timeliness: evidence from Malaysia," Res. Account. Emerg. Econ., vol. 11, no. 2011, pp. 109-127, 2011.

[30] K. Alkhatib and Q. Marji, "Audit Reports Timeliness: Empirical Evidence from Jordan," Procedia - Soc. Behav. Sci., vol. 62, pp. 1342-1349, 2012.

[31] L. Abernathy, John, B. Beyer, A. Masli, and M. Stefaniak, Chad, "How the Source of Audit Committee Accounting Expertise Influences Financial Reporting Timeliness," Curr. Issues Audit., vol. 9, no. 1, pp. 1-9, 2015.

[32] S. Terjesen and E. Couto, "Does the presence of independent and female directors impact firm performance ? A multi-country study of board diversity," J. Manag. Gov., vol. 14, no. January, pp. $1-38,2015$.

[33] K. A. A. Daoud, K. N. I. K. Ismail, and N. A. Lode, "The timeliness of financial reporting among jordanian companies: Do company and board characteristics, and audit opinion matter?," Asian Soc. Sci., vol. 10, no. 13, pp. 191-201, 2014. 